\title{
Effects of Paclobutrazol on Growth and Antioxidant Content of Brassica Rapa Var. Oleifera
}

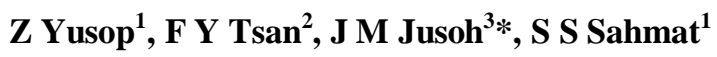 \\ ${ }^{1}$ Faculty of Plantation and Agrotechnology, Universiti Teknologi MARA, Sarawak, \\ 94300 Kota Samarahan, Sarawak, Malaysia. \\ ${ }^{2}$ Faculty of Plantation and Agrotechnology, Universiti Teknologi MARA, 40450 Shah Alam, Selangor, Malaysia. \\ ${ }^{3}$ Faculty of Applied Sciences, Universiti Teknologi MARA Cawangan Sarawak, 94300, Kota Samarahan, Sarawak, Malaysia. \\ *Corresponding author E-mail: junaidahmj@sarawak.uitm.edu.my
}

\begin{abstract}
The experiment was conducted with the main objective was to study the effects of Paclobutrazol (PBZ) on growth and antioxidant content of Brassica rapa var. oleifera. The PBZ was applied at various concentrations $(0,5,10,15$ and $20 \mathrm{mg} / \mathrm{L})$ through seed soaking and seedling as soil drenching. The growth performance data collection was conducted on weekly basis starting from week 3 until week 6 of planting while antioxidant content analyses were conducted on day 38. It was found that PBZ affected the growth and antioxidant content of Brassica rapa var. oleifera. The soil drenching techniques was found significantly affect the plant height, number of leaves and internode length. Similarly, both ascorbic acid and phenolic content were significantly affected by the technique. It was found that application of $10 \mathrm{mg} / \mathrm{L}$ and $5 \mathrm{mg} / \mathrm{L}$ of PBZ has recorded highest amount of ascorbic acid and phenolic content, respectively. This study has proven that the application of PBZ using soil drenching technique on Brassica rapa var. oleifera has contributed to enhancement of its antioxidant content which is also one of the important component in healthy diet intake.
\end{abstract}

Keywords: Paclobutrazol (PBZ); Brassica rapa var. oleifera; seed soaking; soil drenching; antioxidant

\section{Introduction}

Fruits and vegetables are important components for healthy diet due to substantial amount of natural antioxidants contents. Majority of antioxidants can be found in food such as fruits and vegetables, nuts, grains, and some meats, poultry and fish but the most abundant types of antioxidants contained in fruits and vegetables include vitamin C, carotenoids, and phenolics [1]. It has been reported that sufficient amount of fruits and vegetables in daily diet intake can reduce risks and protect us from critical diseases including cancer and cardiovascular diseases. The fruits and vegetables intake guideline in our daily diet have been properly outlined by government agencies and health professionals worldwide. Antioxidants can be defined as substances that may protect or act as "free radical scavengers" and preventing damaging reaction within human cells by supplying positively charge atoms needed to neutralize unstable free radicals that are called "reactive oxygen species" (ROS) or "reactive nitrogen species" [2]. These free radicals are usually produced when our body breaks down food, or by environmental/air exposures like tobacco smoke and radiation. It can also cause serious health problems such as heart diseases, muscular degeneration, diabetes, cancer, inflammation, Parkinson's diseases, and asthma [1][2]. Structural-wise, antioxidants can exist in different chemical structures namely as beta-carotene, lutein, lycopene, lignan, selenium, vitamins $\mathrm{C}$, vitamins $\mathrm{E}$, and vitamins A and others [3].

Vegetables are categorized into seven different types namely bulb vegetables, fruit vegetables, inflorescence vegetables, leafy vegetables, root vegetables, stalk vegetables, and tuber vegetables. Leafy vegetables are also called potherbs, green vegetables, greens, or leafy greens where they are very important part in the human diet. Most leafy vegetables are rich in carotenoids (such as beta carotene), vitamin $\mathrm{C}$, and are good sources of fiber and folate. They also provide varying amount of chlorophyll, iron, and calcium. Brassica rapa $\mathrm{L}$. is one of the leafy vegetables which commonly known as mustard. It comes from the family Cruciferae family (Brassicacea) which is composed of 350 genera and 3500 species [4]. The name of crucifer originally comes from the shape of flowers, with four diagonally opposite petals in the form of a cross. There are several varieties in this species including Brassica rapa var. rapa, Brassica rapa var. oleifera, Brassica rapa var. chinensis, Brassica rapa var. pekinensi, and Brassica rapa var. parachinensis. Brassica rapa var. oleifera has green foliage [4]. The leaves are glabrous or slightly hispid when young, and the upper leaves are partially clasping the stem. The inflorescence is an elongated raceme. The flowers are pale yellow, concisely clustered at the top with open flowers borne at or above the level of terminal buds, and open upwards from the base of the raceme. They have height between $50-250 \mathrm{~cm}$ and have $60-70 \%$ selfpollination but insect and wind also assist pollination. Brassica and many others Brassicacea genera contain glycosinolate compounds that are changed by the myrosinase enzyme to give bitter taste and goitro-genetic substances such as isothiocyanates, thiocyanates, nitrites and goitrin. Brassica is the vital genus which is important annual and biennial foliage and root vegetables [4]. Paclobutrazol (PBZ), with the chemical name of (2RS, 3RS)-1-(4chlorophenyl)-4,4-dimethyl-2-(1H-1,2,4-triazol-1-yl)pentan-3-ol), is a triazole type plant growth retardant which prevents gibberellins biosynthesis and involved in decreasing abscisic acid, ethylene and indole-3-acetic acid while increasing cytokinin levels. Trizoles have both plant growth regulator and fungicide effects 
[5]. In addition, PBZ can also protect the plants from abiotic and biotic stress. It is also used to reduce the size of plant, improve compactness, and increase other abilities of plant to resist environmental stress [6][7]. The changes of plant morphological parameters observed in PBZ-treated plants include reduced plan growth and intermodal elongation, increase chlorophyll content, chloroplast enlargement, leaf tissue thickening, stimulation of root elongation by the inhibition of giberellin biosynthesis, increased cytokinin synthesis, and epicuticular wax formation [7][8][9][10] PBZ is usually applied to the soil to be absorbed by the roots and transported via the xylem to the upper parts of the plant. Though the role of PBZ on growth performance of plants has been well reported, very limited informations available on the effect of PBZ application on antioxidant content in local vegetables. Hence, there is a need to investigate the efficacy of this compound in improving the antioxidant content in Brassica rapa var. oleifera. The main purposes of this study were to determine the optimum PBZ concentration for enhancing antioxidant content in Brassica rapa var. oleifera by using two different methods of PBZ application onto plant namely seed soaking (SS) and soil drenching (SD). The finding of this study will help in identification of better PBZ application method for effective increment of antioxidant content and adding beneficial properties of Brassica rapa var. oleifera thereby making it valuable crop plant. This will benefits human beings durable to infection.

\section{Materials and Methods}

\subsection{Test Materials}

The seeds and seedlings of 4 leaves of $B$. rapa var. oleifera purchased from a local nursery were used as test materials.

\subsection{Methods}

\subsubsection{Seeds and Seedlings Treatments}

The overall treatments on seed and seedlings were conducted under the rain shelter. The seeds were disinfected in $1 \%$ sodium hypochlorite solution for $10 \mathrm{~min}$ to eliminate possible seed-borne microorganisms. Then, the seeds were rinsed 3 times with distilled water. The seeds were randomly divided into 2 sets. First set of the seeds was germinated in germination trays. After 2 weeks, the seedlings were transferred to $15 \mathrm{~cm} \times 20 \mathrm{~cm}$ polybags with potting mixture of 3:2:1 (peat moss: soil: sand). After 1 week of transfer, the plants with 6 leaves were subjected to PBZ application by soil drenching (SD). Second set of seeds was soaked with PBZ prior to germination followed by seedlings transfer into polybags with similar dimension mentioned earlier. This seed soaking (SS) method was applied at concentrations of 0 (control), 5, 10, 15 and $20 \mathrm{mg} / \mathrm{L}$. Watering was carried out accordingly to maintain an adequate moisture level in the growth medium. The treatments were arranged according to a CRD with 6 replicates.

\subsubsection{Growth Performance Measurement}

The survival of the treated seeds and seedlings, and the growth performance of the plants were recorded weekly. The parameters recorded including plant height, crown diameter, the leaf size (length and width of leaves), number of leaves and chlorophyl content. The freshly harvested plants of each treatment were recorded for their fresh shoot weight, fresh root weight and the length of internode at 4th leaf. The chlorophyll content of those plants was measured using SPAD 502 Plus Chlorophyll Meter. The samples were also subjected to antioxidant analyses on $38^{\text {th }}$ day of experiment. Two parameters were measured including Ascorbic Acid (AA) and Total Phenolic Content (TPC).

\subsubsection{Determination of Ascorbic Acid (AA)}

Ascorbic Acid (AA) content was quantitatively determined using the 2, 6-dichloroindophenol (DCIP) dye method as described by [11] and [12] with slight modification. In this procedure, $2 \mathrm{~g}$ of each fresh sample was mixed with $8 \mathrm{~mL}$ of cold extracting solution. This cold extracting solution was stored at $4{ }^{\circ} \mathrm{C}$ and consisted of $30 \mathrm{~g}$ metaphosphoric acid, $80 \mathrm{~mL}$ of acetic acid and distilled water added to $1000 \mathrm{ml}$. The mixture was homogenized in a blender for $1 \mathrm{~min}$ and then filtered through filter paper to eliminate particulates. The result was AA extract. To quantify AA content, $5 \mathrm{ml}$ of AA extract was titrated with DCIP solution (i.e. 25 $\mathrm{mg}$ DCIP and $21 \mathrm{mg} \mathrm{NaHCO}$ in $75 \mathrm{~mL}$ water) until pink colour. The DCIP solution was standardized with AA solution. All determinations were repeated three times, and the results were expressed as mg AA per 100 gram of fresh weight basis (unit written as $\mathrm{mg} 100 / \mathrm{g}$ ).

\subsubsection{Determination of Total Phenolic Content (TPC)}

The total phenolic acid of the B. rapa var. oleifera was determined by using Folin-Ciocalteu reagent following a slightly modified method [13] [14]. Gallic acid was used as a reference standard for plotting calibration curve. The total phenolic contents were determined from the linear equation of a standard curve prepared with gallic acid. The test material was dried at $60^{\circ} \mathrm{C}$ in an oven and the dried sample was used to determine the phenolic content. Gallic acid stock solution was first prepared by dissolving $0.01 \mathrm{~g}$ dry gallic acid into $100 \mathrm{~mL}$ distilled water. The stock solution was used for the calibration curves of standard gallic acid. The standard gallic acid solutions of $0.0,0.05,0.1 .0 .2,0.3,0.5 \mathrm{mg} / \mathrm{L}$ were then prepared accordingly. To determine the phenolic content in the sample, $2 \mathrm{~g}$ dried leaf sample was placed in $40 \mathrm{~mL}$ distilled water and heated at $60^{\circ} \mathrm{C}$ for 60 minutes. $100 \mu \mathrm{L}$ sample solution was pipetted into small bottle. All the standard gallic acid solutions and sample solutions were each added with $1 \mathrm{~mL}$ of $50 \%$ Folin-Ciocaltue reagent and the mixture was left for 5 minutes. Then, $2 \mathrm{~mL}$ of $2 \%$ sodium carbonate solution and $7 \mathrm{~mL}$ distilled water were added into each mixture and agigated. The standard and the sample solutions were left in the dark for two hours and measured at 760nm by using UV-spectrophotometer. Quantitative results were then expressed with reference to gallic acid. Results on the total phenols were expressed as $\mathrm{mg} / \mathrm{g}$ gallic acid equivalents (GAE) of dry extract.

\subsubsection{Statistical Analysis}

ANOVA was carried out at 5\% level of significance. Treatment means were compared by using Tukey's Simultaneous Test.

\section{Results and Discussion}

\subsection{Effects of PBZ on Growth Performance}

As reported in Table 1, growth inhibition of B. rapa var. oleifera by PBZ in terms of height was noticeable with SD as compared to SS application. This result was in agreement with those reported by [6], [7], [15] and [16] that stated reduced plant height with higher PBZ concentration applied as soil drenching. According to [7], PBZ was found effective in reducing height of garden pansy plant (Viola $x$ wittrockiana Gams.) from $8.17 \mathrm{~cm}$ to $6.60 \mathrm{~cm}$ when applied at $2.5 \mathrm{pm}$ and $5.0 \mathrm{ppm}$, respectively. PBZ reduced plant height by blocking multiple steps in biosynthesis of gribberellins and steroids. The research conducted by [16] also reported that plant height of Nerium oleandar L. seedling was significantly inhibited by PBZ (37\% reduction compared with the control). Research conducted by [17] also showed that the height of Okra significantly decreased with an increase in the concentration of PBZ applied to the soil. 
Table 1: ANOVA and Mean Comparison for Plant Heights (in $\mathrm{cm}$ )

\begin{tabular}{lccccc}
\hline \multirow{2}{*}{ Source } & df & \multicolumn{5}{c}{$p$-value for period in days } \\
\cline { 3 - 6 } & & 21 & 28 & 32 & 36 \\
\hline Treatment & $\mathbf{1}$ & $\mathbf{0 . 6 1 9}$ & $\mathbf{0 . 0 2 2}$ & $\mathbf{0 . 0 0 0}$ & $\mathbf{0 . 0 0 0}$ \\
PBZ con- & & & & & \\
centration & 4 & 0.492 & 0.463 & 0.203 & 0.058 \\
Interaction & 4 & 0.741 & 0.602 & 0.360 & 0.584 \\
\hline Period (days) & & 21 & 28 & 32 & 36 \\
\hline Treatment & & & & \\
SS & & $13.63 \mathrm{a}$ & $18.03 \mathrm{a}$ & $22.55 \mathrm{a}$ & $32.27 \mathrm{a}$ \\
SD & & $15.11 \mathrm{a}$ & $15.37 \mathrm{~b}$ & $18.29 \mathrm{~b}$ & $21.30 \mathrm{~b}$
\end{tabular}

Means with the same letter within the same column are not significantly different at $5 \%$ level of significance.

On the contrary, soil drenching of $B$. rapa var. oleifera seedling resulted in emergence of more leaves but the leaves were significantly smaller in terms of leaf width, as shown in Table 2 and 3, respectively. Application of PBZ to B. rapa var. oleifera by using SD technique resulted in the development of more leaves from 28 days after planting. Similarly, high application concentration of $\mathrm{PBZ}$ at $20 \mathrm{mg} / \mathrm{L}$ also resulted in increased number of leaves as compared to control treatment. This result was in agreement with those reported by [18] where PBZ was also found to increase the number leaves and roots in both wheat cultivars, i.e. Ghods and Karchia. Research conducted by [17] on Okra showed that number of leaves/plant increased with an increase in PBZ concentration with values ranged from 30.59 to 38.81 as compared to the control treatment.

Table 2: ANOVA and Mean Comparison for Number of Leaves

\begin{tabular}{lccccc}
\hline \multirow{2}{*}{ Source } & \multirow{2}{*}{ df } & \multicolumn{4}{c}{$p$-value for period in days } \\
\cline { 3 - 6 } $\begin{array}{l}\text { Treatment } \\
\text { PBZ con- }\end{array}$ & $\mathbf{1}$ & $\mathbf{0 . 4 7 1}$ & $\mathbf{0 . 0 0 2}$ & $\mathbf{0 . 0 0 0}$ & $\mathbf{0 . 0 0 0}$ \\
centration & $\mathbf{4}$ & $\mathbf{0 . 1 5 7}$ & $\mathbf{0 . 0 0 0}$ & $\mathbf{0 . 0 0 0}$ & $\mathbf{0 . 0 0 0}$ \\
Interaction & 4 & 0.344 & 0.234 & 0.505 & 0.867 \\
\hline Period (days) & 21 & 28 & 32 & 36 \\
\hline $\begin{array}{l}\text { Treatment } \\
\text { SS }\end{array}$ & $7.55 \mathrm{a}$ & $12.30 \mathrm{~b}$ & $16.20 \mathrm{~b}$ & $20.30 \mathrm{~b}$ \\
SD & $7.30 \mathrm{a}$ & $14.55 \mathrm{a}$ & $20.75 \mathrm{a}$ & $27.10 \mathrm{a}$ \\
\hline Period (days) & 21 & 28 & 32 & 36 \\
\hline PBZ concentra- & & & & \\
tion (mg/L) & & & & \\
0 & $7.00 \mathrm{a}$ & $9.375 \mathrm{c}$ & $13.125 \mathrm{c}$ & $15.875 \mathrm{c}$ \\
5 & $7.88 \mathrm{a}$ & $12.250 \mathrm{bc}$ & $17.00 \mathrm{bc}$ & $22.250 \mathrm{~b}$ \\
10 & $7.75 \mathrm{a}$ & $14.125 \mathrm{ab}$ & $19.250 \mathrm{~b}$ & $23.875 \mathrm{~b}$ \\
15 & $6.75 \mathrm{a}$ & $14.875 \mathrm{ab}$ & $19.375 \mathrm{ab}$ & $25.625 \mathrm{ab}$ \\
20 & $7.75 \mathrm{a}$ & $16.50 \mathrm{a}$ & $23.625 \mathrm{a}$ & $30.875 \mathrm{a}$ \\
\hline
\end{tabular}

Means with the same letter within the same column are not significantly different at $5 \%$ level of significance.

As shown in Table 4, neither SD nor SS was found significantly affect the leaf length of $B$. rapa var. oleifera. This finding was found in agreement with previous study conducted by [19] which reported that application of PBZ on white oak did not affect the leaf size (length and width) or twig growth at any time during the 7 years of his study. The effects of PBZ on plant growth inhibition were presumed to be dependent on genetic makeup of plants besides the application concentration and method as studied. However, [17] reported that the fifth leaf of okra plant showed significant decreased leaf area with all concentrations of PBZ studied as compared with the control treatment. Results from previous study conducted by [20] also showed that increasing the concentration of PBZ treatment resulted in decreased shoot length, internode length, leaf area, leaf index, weight, length, diameter of fruit and also fruit acidity. Overall, as shown in Table 5 and Fig. 1, the crown diameter of B. rapa var. oleifera under study was not sig- nificantly different irrespective of any concentration or the PBZ application technique.

Table 3: ANOVA and Mean Comparison for Leaf Width

\begin{tabular}{lccccc}
\hline \multirow{2}{*}{ Source } & \multirow{2}{*}{ df } & \multicolumn{4}{c}{$p$-value for period in days } \\
\cline { 3 - 6 } & & 21 & 28 & 32 & 36 \\
\hline Treatment & $\mathbf{1}$ & $\mathbf{0 . 0 2 7}$ & $\mathbf{0 . 0 0 0}$ & $\mathbf{0 . 0 0 0}$ & $\mathbf{0 . 0 0 0}$ \\
& & & & & \\
PBZ con- & & 0.193 & 0.265 & 0.337 & 0.491 \\
centration & 4 & & & & \\
& & & & & \\
Interaction & 4 & 0.223 & 0.819 & 0.732 & 0.764 \\
\hline Period (days) & & 21 & 28 & 32 & 36 \\
\hline $\begin{array}{l}\text { Treatment } \\
\text { SS }\end{array}$ & & $7.88 \mathrm{a}$ & $9.50 \mathrm{a}$ & $11.00 \mathrm{a}$ & $12.4 \mathrm{a}$ \\
SD & $7.40 \mathrm{~b}$ & $8.20 \mathrm{~b}$ & $9.175 \mathrm{~b}$ & $10.75 \mathrm{~b}$ \\
\hline
\end{tabular}

Means with the same letter within the same column are not significantly different at $5 \%$ level of significance.

\begin{tabular}{|c|c|c|c|c|c|}
\hline \multirow{2}{*}{ Source } & \multirow{2}{*}{ df } & \multicolumn{4}{|c|}{$p$-value for period in days } \\
\hline & & 21 & 28 & 32 & 36 \\
\hline Treatment & 1 & 0.453 & 0.092 & 0.028 & 0.131 \\
\hline $\begin{array}{l}\text { PBZ con- } \\
\text { centration }\end{array}$ & 4 & 0.170 & 0.652 & 0.754 & 0.654 \\
\hline Interaction & 4 & 0.287 & 0.871 & 0.902 & 0.296 \\
\hline
\end{tabular}

\begin{tabular}{|c|c|c|c|c|c|}
\hline \multirow{2}{*}{ Source } & \multirow{2}{*}{ df } & \multicolumn{4}{|c|}{$p$-value for period in days } \\
\hline & & 21 & 28 & 32 & 36 \\
\hline Treatment & 1 & 0.390 & 0.288 & 0.787 & 0.626 \\
\hline $\begin{array}{l}\text { PBZ con- } \\
\text { centration }\end{array}$ & 4 & 0.494 & 0.889 & 0.270 & 0.171 \\
\hline Interaction & 4 & 0.731 & 0.970 & 0.597 & 0.287 \\
\hline
\end{tabular}

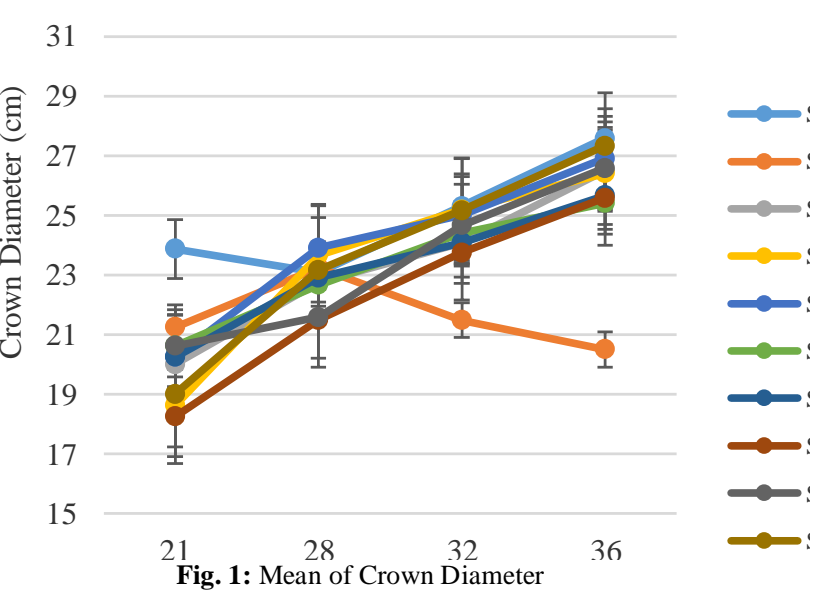

Table 6 shows the statistical analysis for internode length measurement conducted on day 38 of experiment. The internode length was significantly affected by PBZ application using SD technique where reduction of internode length was noticed in $B$. rapa var. oleifera. The plants had significantly shorter internodes as compared to those treated by PBZ using SS. All PBZ treated plants also had significantly shorter internode length as compared to control treatment. Increasing of PBZ treatment concentration also significantly decreased the internode length of $B$. rapa var. oleifera. PBZ application at $20 \mathrm{mg} / \mathrm{L}$ was more effective in decreasing the internode length as compared to those treated with lower concentrations. This result was also similar to those reported by [21]. They reported PBZ treatment on Lycopersicon 
esculentum Mill. has recorded 68\% reduction and $22 \%$ increase of internode length and stem thickness, respectively.

Table 6: ANOVA and Mean Comparison for Internode Length on Day 38

\begin{tabular}{lcc}
\multicolumn{1}{c}{ Source } & df & $p$-value for period on Day 38 \\
\hline Treatment & $\mathbf{1}$ & $\mathbf{0 . 0 0 0}$ \\
PBZ concentration & $\mathbf{4}$ & $\mathbf{0 . 0 0 0}$ \\
Interaction & 4 & 0.079 \\
\hline Treatment & $1.2150 \mathrm{a}$ \\
SS & $0.7250 \mathrm{~b}$ \\
SD & \\
PBZ concentration (mg/L) & $1.5625 \mathrm{a}$ \\
0 & $1.0000 \mathrm{~b}$ \\
5 & $0.9250 \mathrm{~b}$ \\
10 & $0.7125 \mathrm{~b}$ \\
15 & $0.6500 \mathrm{~b}$ \\
20 & \\
\hline Means with the same letter within the same column are not significantly \\
different at 5\% level of significance.
\end{tabular}

As shown in Table 7, application of PBZ to B. rapa var. oleifera by means of SS or SD did not significantly affect the relative chlorophyll content over the study period of 5 weeks. Fig. 2 also clearly show that PBZ application at concentrations up to $20 \mathrm{mg} / \mathrm{L}$ also did not significantly affect the chlorophyll content of $B$. rapa var. oleifera. This finding was found contrary to study reported by [22] that PBZ treatment increased the relative water and chlorophyll content of mango seedlings.

Table 7: ANOVA for Chlorophyll Content

\begin{tabular}{lccccc}
\hline \multicolumn{1}{c}{ Source } & df & \multicolumn{4}{c}{$p$-value for period in days } \\
\cline { 3 - 6 } & & 21 & 28 & 32 & 36 \\
\hline Treatment & 1 & 0.110 & 0.941 & 0.079 & 0.110 \\
PBZ concentration & 4 & 0.321 & 0.951 & 0.284 & 0.321 \\
Interaction & 4 & 0.953 & 0.184 & 0.664 & 0.953 \\
\hline
\end{tabular}

As can be seen in Table 8 , fresh shoot weight was significantly affected by the PBZ treatment. In specific, seedlings drenched with PBZ generally had relatively lower fresh weight as compared to those treated with SS as shown in Table 9. This finding was found aligned to study reported by [8] where by using SD technique, the PBZ application was markedly as second most effective agent (after uniconazole) for suppressing shoot growth of Euryops. Pectiantus Cass.

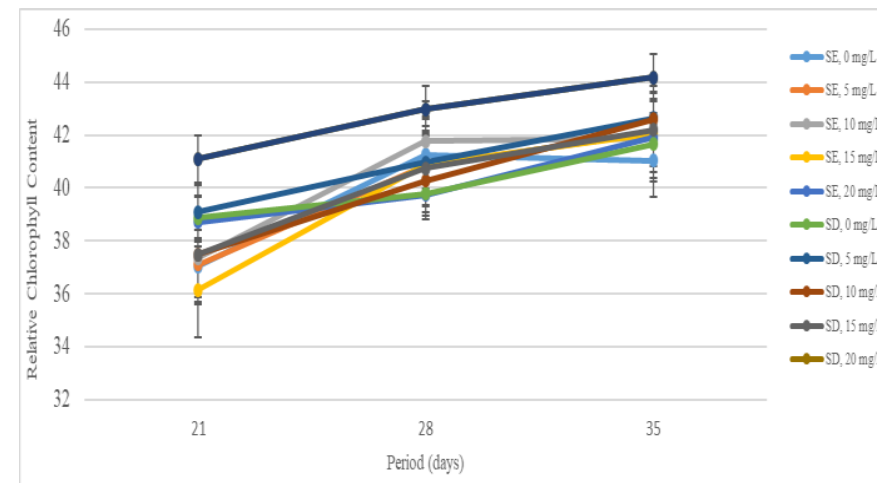

Fig. 2: Mean of Chlorophyll Content

On the other hand, PBZ did not significantly affect both root growth and root:shoot ratio as clearly shown by Fig. 3 and Fig. 4 , respectively. In relation to the fresh root weight, [23] also reported that fresh weight, number and diameter of roots were not affected by PBZ. However, [24] stated that PBZ treated tomato plantlets recorded higher fresh weight of roots as compared to control in $\mathrm{NaCl}$ salinity media under in vitro condition.

Table 8: ANOVA of Shoot Weight, Root Weight and Root:Shoot Ratio on Day 38

\begin{tabular}{llccc}
\multirow{2}{*}{ Source } & \multirow{2}{*}{ df } & \multicolumn{3}{c}{$p$-value for period in days } \\
\cline { 3 - 5 } & & Shoot & Root & Root: Shoot \\
\hline Treatment & $\mathbf{1}$ & $\mathbf{0 . 0 0 9}$ & 0.217 & 0.629 \\
PBZ concentration & 4 & 0.764 & 0.285 & 0.091 \\
Interaction & 4 & 0.862 & 0.924 & 0.437
\end{tabular}

Table 9: Mean Comparison for Shoot Weight on Day 38

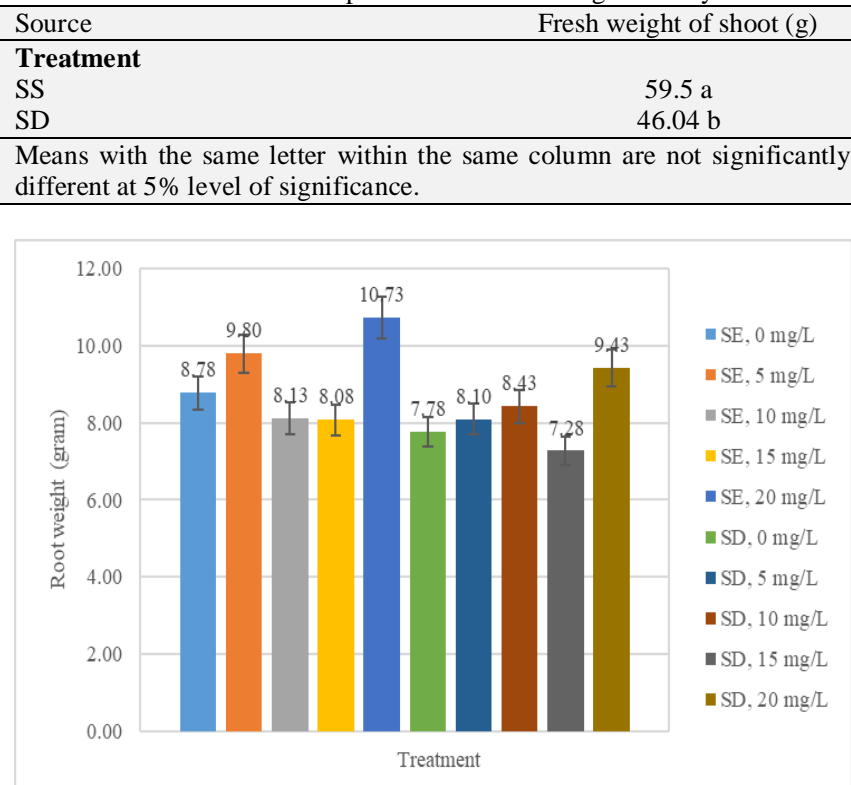

Fig. 3: Mean of Fresh Root Weight

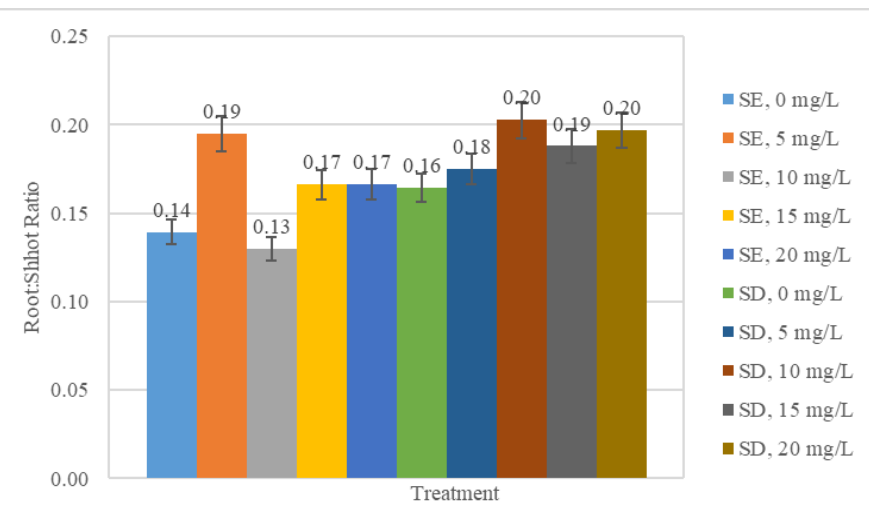

Fig. 4: Mean of Root:Shoot Ratio

\subsection{Effects of PBZ on Antioxidant Content}

Antioxidant content in terms of AA in B. rapa var. oleifera was significantly affected by PBZ application method and concentration and the result is shown in Table 10. Plants treated with SD method had significantly recorded higher AA content as compared to SS method. It was found that interaction between SD method and $10 \mathrm{mg} / \mathrm{L}$ PBZ resulted in the highest AA content. Several studies including [6], [25], [26], [27] and [28] also reported that application of PBZ induced biochemical adaptations including increasing the AA. According to study conducted by [25], PBZ application was found increased the AA content of leaves and stem tissues of Ocimum sanctum to $158.18 \%$ and $119.02 \%$ over the control on Diammonium Phosphate (DAP) fertilizer. According to [26], PBZ treated drought stressed plants maintained higher levels of antioxidant and scavenging enzymes. Previous study by 
[27] also reported increased AA contents in the leaves and storage roots of triazole treated sweet potato plants. An increase in AA content was also reported by [28] in uniconazole treated tomato seedlings and paclobutrazol treated Dioscorea rotundata. As shown in Fig. 5, the phenolic content was generally higher in plants applied with PBZ as SD of seedling as compared to SS treatment. Application of PBZ by SD method at concentration of 5 $\mathrm{mg} / \mathrm{L}$ gave highest amount of phenolic content.

Table 10: ANOVA and Mean Comparison of AA on Day 38

\begin{tabular}{|c|c|c|}
\hline Source & $\mathrm{df}$ & $p$-value for period on Day 38 \\
\hline Treatment & 1 & 0.000 \\
\hline PBZ concentration & 4 & 0.000 \\
\hline Interaction & 4 & 0.000 \\
\hline $\begin{array}{l}\text { Treatment } \\
\text { Seed } \\
\text { Seedling } \\
\text { PBZ concentration }\end{array}$ & & $\begin{array}{l}6.133 \mathrm{~b} \\
11.199 \mathrm{a}\end{array}$ \\
\hline 0 & & $12.332 \mathrm{a}$ \\
\hline 5 & & $11.110 \mathrm{~b}$ \\
\hline 10 & & $7.777 \mathrm{~b}$ \\
\hline 15 & & $6.222 \mathrm{~b}$ \\
\hline 20 & & $5.888 \mathrm{~b}$ \\
\hline \multicolumn{3}{|l|}{ Interaction } \\
\hline Treatment & $\begin{array}{l}\text { PBZ Con- } \\
\text { centration }\end{array}$ & \\
\hline \multirow{5}{*}{ SS } & 0 & $5.999 \mathrm{c}$ \\
\hline & 5 & $5.333 \mathrm{c}$ \\
\hline & 10 & $7.110 \mathrm{bc}$ \\
\hline & 15 & $5.777 \mathrm{c}$ \\
\hline & 20 & $6.444 \mathrm{~b} \mathrm{c}$ \\
\hline \multirow{5}{*}{ SD } & 0 & $5.777 \mathrm{c}$ \\
\hline & 5 & $7.110 \mathrm{c}$ \\
\hline & 10 & $17.554 \mathrm{a}$ \\
\hline & 15 & $9.777 \mathrm{~b}$ \\
\hline & 20 & $15.776 \mathrm{a}$ \\
\hline
\end{tabular}

Means with the same letter within the same column are not significantly different at $5 \%$ level of significance.

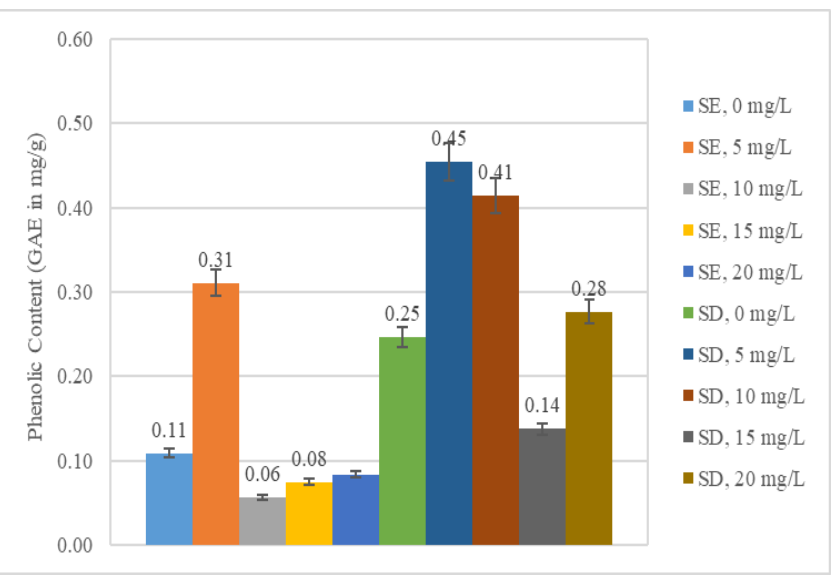

Fig. 5: Mean of Phenolic Content (GAE in $\mathrm{mg} / \mathrm{g}$ )

\section{Conclusion}

From the results of this study, it can be concluded that the application of PBZ affected the growth performance and antioxidant content of B. rapa var. oleifera. It was found that application of
$10 \mathrm{mg} / \mathrm{L}$ and $5 \mathrm{mg} / \mathrm{L}$ of PBZ using soil drenching technique recorded highest amount of ascorbic acid and phenolic content, respectively. Further experiments considering higher PBZ application concentrations and times with other major phytochemical antioxidants in B. rapa var. oleifera are required in order to identify effective concentration for optimum plant growth.

\section{Acknowledgement}

The authors are thankful to Faculty of Plantation and Agrotechnology UiTM for the support and assistance during data collection.

\section{References}

[1] Kalt, W., "Effect of production and processing factors on major fruit and vegetable antioxidant", Journal of Food Sciences, Vol. 70 , No. 1, (2005), pp. 11-19.

[2] Benbrook, C., Elevating Antioxidant Levels in Food through Organic Farming and Food Processing, The Organic Centre for Education and Promotion, (2005), pp. 2-10.

[3] Pham-Huy, L.A., He, H., \& Pham-Huy, C., "Free Radicals, Antioxidants in Disease and Health", International Journal of Biomedical Sciences, Vol. 4, No. 2, (2008), pp. 89-96.

[4] Podsedek, A., "Natural Antioxidant and Antioxidant Capacity of Brassica Vegetables: A review", LWT Food Sciences and Technology, Vol. 40, (2007), pp. 1-11.

[5] Nazarudin, A., Fauzi, R., \& Tsan, F.Y., "Effects of Paclobutrazol on the growth and anatomy of stems and leaves of Syzygium Campanulatum", Journal of Tropical Forest Science, Vol. 19, No. 2, (2007), pp. 86-91.

[6] Xiang, X., Yuhan, T., Mengran, W., \& Daqiu, Z., "Effect of Paclobutrazol application on plant photosynthetic performance and leaf greenness of herbaceous peony", Journal of Horticulturae, Vol. 4 (1), No. 5, (2018), pp. 1-12, available online: https://doi.org/10.10.3390/horticulturae401005.

[7] Ayandip, B., Tapas, M., Srabani., D., \& Bipra., T., "Effect of plant growth regulators on growth and flowering of Pansi (Viola $x$ wittrockiana Gams.) under West Bengal conditions", International Journal of Current Microbiology and Applied Sciences, Vol. 7, No. 1, (2018), pp. 2125-2130, available online: https://doi.org/10.20546/ijcmas.2018.701.256.

[8] Yasuhiko, K., Ken-ichi, M., Yozo., M., \& Ok-Kyung., K., "Effects of Uniconazole-P and Paclobutrazol application on the growth and flowering of Euryops Pectinatus Cass.", Journal of Advanced Agricultural Technologies, Vol. 5, No. 1, (2018), pp. 31-35, available online: https://doi.10.18178/joaat.5.1.31-35.

[9] Chen, Y., Kessler, J.R., Keever, G.J, \& Fain, G.B., "Effects of growing season, plant stage of development, and substrate drench applications of paclobutrazol as compared to a Daminozide standard on growth and flowering of Gerbera Daisy 'Bright Red with Light Eye'”, Journal of Environmental Horticulture, Vol. 36, No. 2 (2018), pp. 66-72, available http://hrijournal.org/doi/pdf/10.24266/JEH-S-18-00004.1.

[10] Jarunee, J., Kobkiat, S., \& Jamnong, U., "Effects of water-deficit stress and paclobutrazol on growth, relative water content, electrolyte leakage, proline content and some antioxidant changes in Cursuma alismatifolia Gagnep. Cv. Chiang Mai Pink", Saudi Journal of Biological Sciences, Vol. 24, (2017), pp. 1505-1512, available online: http://dx.doi.org/10.1016/j.sjbs.2015.09.017.

[11] Singh, J., Dilta, B., Gupta, Y., Sharma, B., Baweja, H., \& Kaushal, "Effect of growing media and paclobutrazol on growth, flowering and pot presentability of geranium, Pelargonium $x$ hortorum LH Bailey", International Journal of Farm Sciences, Vol. 6, No. 2, (2016), pp. 128-136.

[12] AOAC, Official Methods of Analysis, AOAC International, (1995), Washighton, DC.

[13] Fatma, A., Sokindra, K., \& Shah, A.K., "Estimation of total phenolic content, in-vitro antioxidant and anti-inflammatory activity of flowers of Moringa oleifera", Asian Pacific Journal of Tropical Biomedicine, Vol. 3, No. 8, (2013), pp. 623-627.

[14] Gabriel, A.A., Joe, A.V., \& Patrick, E.D., "Folin-Ciocaltue Reagent for Polyphenolic Assay", International Journal of Food Science, Nutrition and Dietitics, Vol. 3, No. 801, (2014), pp. 1-10. 
[15] Pardos, M., Calama, R., \& Montero, G., "Growth of containergrown cork oak seedling as affected by foliar and soil application of Paclobutrazol", HortScience, Vol. 40, No. 6, (2005), pp. 1173-1176.

[16] Ochan, J., Franco J.A., Banon, S., \& Fernandez, J.A., "Distribution in plant, substrate and leachate of Paclobutrazol following application to containerized Nerium oleander L. Seedlings", Spanish Journal of Agricultural Research, Vol. 7, No. 3, (2009), pp. 621-628. available

online: https://pdfs.semanticscholar.org/d0c1/06ece2e8822d62d50fca0daa0 fd015a49f8c.pdf?_ga=2.218995280.857572086.15352589441315289942.1535258944.

[17] Benjawan, C., Chutichudet, P., \& Chanaboon, T., "Effect of chemical Paclobutrazol on growth, yield and quality of okra (Abelmoschus esculentus L.) Har Lium cultivar in northeast Thailand", Pakistan Journal of Biological Sciences, Vol. 10, No. 3, (2007), pp. 433-438. available online: https://scialert.net/abstract/?doi=pjbs.2007.433.438.

[18] Hajihashemi, S., Kiarostami, K., Enteshari, S., \& Saboora, A., "The effect salt stress and Paclobutrazol on some physio-logical parameters of two salt-tolerant and salt-sensitive cultivars of wheat", Pakistan Journal of Biological Sciences, Vol. 9, (2006), pp. 1370-1374.

[19] Watson, G.W., "The effect of Paclobutrazol treatment on starch content, Mycorrhizal colonization, and fine root density of white Oaks (Quercus alba L.)", International Society of Arboriculture, Vol. 32, No.3, (2006), pp. 114-117.

[20] Fawzy, M.I.F., \& Elham, Z.A., "Effect of some growth retardants on growth, yield and quality of "Le-Conte" pears", Minufiy Journal of Agricultural Research, Vol. 30, No. 3, (2005), pp. 999-1010.

[21] Berova, M., \& Zlatev, Z., "Physiological response and yield of paclobutrazol treated tomato plants (Lycopersicon esculentum Mill.)", Plant Growth Regulation, Vol. 30, (2000), pp. 117-123.

[22] Kishor, A., Srivastav, M., Dubey, A.K., Singh,A.K, Sairam,R.K., Pandey, R.N., Dahuja, A., \& Sharma, R.R., "Paclobutrazol minimises the effects of salt stress in mango (Mangifera indica L.)", The Journal of Horticultural Science and Biotechnology, Vol. 84, No. 4, (2001), pp. 459-465.

[23] Shakeri, F., Baninasab, B., Ghobadi, C., \& Mobli, M., "Effect of Paclobutrazol concentration and application methods on vegetative and reproductive growth of strawberry (Fragaria $\times$ Ananassa Duch. cv. Selva)", Journal of Horticulture Science, Vol. 1388, No. 23, (2010), pp. 2564-2572.

[24] Roghaieh, B., Behrooz, E., Hassan, M.L., \& Hokmalipour, S., "Paclobutrazol and salicylic acid affects salinity resistance of tomato under in vitro condition", Middle-East Journal of Scientific Research, Vol. 7, No. 6, (2011), pp. 915-918.

[25] Nair, V.D., Cheruth, A.J., Gopi, R., Gomathinayagam, M., \& Panneerselvam, R., "Antioxidant potential of Ocimum sanctum under growth regulator treatment ", EurAsian Journal of BioSciences, Vol. 3, (2009), pp. 1-9.

[26] Sankar, B., Jaleel, C.A., Manivannan, P., Kishorekumar, A., Somasundaram, R., \& Pannerselvam, R., "Effect of Paclobutrazol on water stress amelioration through antioxidant and free radical scavenging enzymes in Arachis hypogaea L.", Colloids Surf B Biointerfaces, Vol. 60, (2007), pp. 229-235.

[27] Sivakumar, T., Lakshmanan, G.M.A., Murali, P.V., \& Panneerselvam, R., "Alteration of antioxidative, metabolism induced by triazoles in Sweet Potato", Journal of Experimental Sciences, Vol. 1, No. 3, (2010), pp. 10-13.

[28] Scandalios, J.G., Guan, L., \& Polidoros, A.N., Oxidative Stress and the Molecular Biology of Antioxidant Defenses, Cold Spring Harbor Laboratry, Cold Spring Harbor, New York, USA, (1997), pp. 343 406.

[29] Martinaze-Trinidad, T., Watson, W.T., \& Book, "Impact of Paclobutrazol on root-pruned live oak", Hort Technology, Vol. 21, No. 1, (2011), pp. 46-50.

[30] Chao-Chia, T., Kuan-Hung, R. L., Shih-Ying, H., Long-Fang O. C., \& Hsiao-Feng L., "Paclobutrazol pre-treatment enhance flooding tolerance of sweet potato", Journal of Plant Physiology, Vol. 163, (2005), pp. 750-760. 